THE GREAT FINANCIAL CRISIS AND ITS AFTERMATH:

A PERSPECTIVE FROM ASIA

\author{
Hans Genberg
}

The South East Asian Central Banks (SEACEN) Research and Training Centre (80416-M)

Kuala Lumpur, Malaysia 
WORKING PAPER 21/2017

\title{
THE GREAT FINANCIAL CRISIS AND ITS AFTERMATH: A PERSPECTIVE FROM ASIA*
}

\author{
Hans Genberg
}

\section{April 2017}

* Forthcoming in World Scientific Studies in International Economics: Forthcoming in Douglas D. Evanoff; George G Kaufman; Agnese Leonello and Simone Manganelli , (Eds.), 2017, Achieving Financial Stability, World Scientific. 
Table of Contents

Page

1. Introduction

2. Resilience in the Face of Global Turbulence: Good Policies or Good Fortune?

3. Policies and Governance

4. Good Fortune

5. Potential Side Effects

6. Concluding Remarks

References

Disclaimer: This Working Paper should not be reported as representing the views of SEACEN or its member central banks/monetary authorities. The views expressed in this Working Paper are those of the author(s) and do not necessarily represent those of SEACEN or its member central banks/monetary authorities. 


\title{
THE GREAT FINANCIAL CRISIS AND ITS AFTERMATH: A PERSPECTIVE FROM ASIA
}

\author{
By \\ Hans Genberg
}

\section{Introduction}

Compared to advance economies in the West, Asian emerging market have recovered relatively well from the Great Recession of 2008-09 A contributory factor were lessons learned from the Asian Financial Crisis (AFC) of 1997-98 which led to changes in governance frameworks and policy strategies that rendered economies in the region more resilient. This note also suggests that an element of good fortune may have been present.

The good economic performance notwithstanding, policy makers must guard against complacency. They need to ensure that possible side effects of current policy frameworks are kept at a minimum, and that the frameworks themselves evolve with changes in the global economy.

\section{Resilience in the Face of Global Turbulence: Good Policies or Good Fortune?}

The Great Financial Crisis (GFC) that shook financial markets principally in the United States and Europe did not have the same devastating impact on markets in Asia. ${ }^{1}$ To be sure, economic activity slowed markedly in the region, but this was principally the result of declining external demand resulting from the Great Recession in the West. Finance contributed to the slowdown as trade credit dried up, but when the acute phase of the GFC was over, real GDP returned to the previous trend line, contrary to what took place in the Euro Area and the United States. (Figure 1) The crisis, which has led to a persistent decline in real GDP, and arguably also a decline in its growth rate, in both the Euro Area and in the United States, does not appear to have had similar consequences in Asia. Was this the result of good policies or good luck?

\footnotetext{
1 Observers in Asia find the term Global Financial Crisis disingenuous for this reason. Why, they ask, should we refer to the US-European financial crisis a global crisis, when we called the financial crisis in 1997-98 the Asian Financial Crisis.
} 


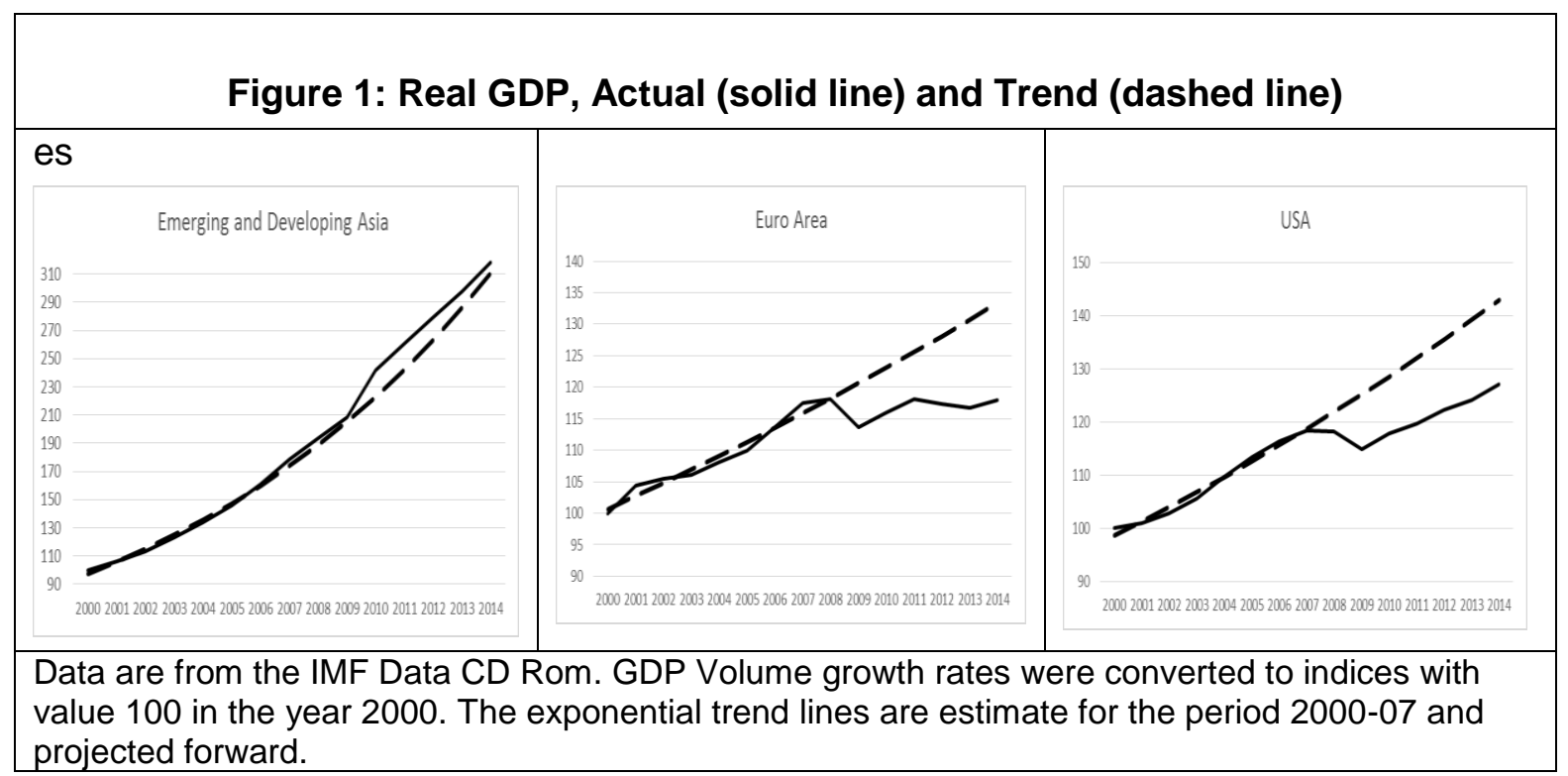

\section{Policies and Governance}

Before the Asian Financial Crisis central bank policies in most emerging Asian economies focused principally on maintaining stable exchange rates. Together with increasing openness to capital inflows and outflows, this focus implied a significant vulnerability to sudden stops in capital inflows, hence the crisis in 1997-98.

Since the AFC most central banks in the region have adopted price stability as their main objective. Several central banks are self-proclaimed inflation targeters; Bank Indonesia, Bangko Sentral ng Pilipinas, Bank of Thailand, and more recently the Reserve Bank of India. Others, for example Peoples Bank of China, Bank Negara Malaysia and the Central Bank of Sri Lanka, do not count themselves as inflation targeters even if price stability figures prominently as one of their objectives.

Filardo and Genberg (2010) argue that greater focus by central banks on inflation control has translated into a lower and more stable inflation environment. They also show that it is difficult to document big differences in inflation performance between explicit inflation targeters and noninflation targeters. In other words, there is no one-size-fit-all recipe for ensuring macroeconomic stability provided that there is a broad consensus about the importance of inflation control. In a number of Asian economies such a consensus has translated into greater central bank independence and improved governance further reinforcing policy frameworks. 
Greater focus on inflation has gone hand in hand with a willingness to allow significantly more variability in nominal exchange rates. This does not imply complete laissez faire with respect to exchange rate movements. In fact, most central banks intervene in the foreign exchange market to 'reduce volatility' which should be interpreted as attempting to prevent significant misalignments of exchange rates as well as to maintain orderly foreign exchange markets.

A significant increase in exchange rate flexibility together with a focus by central banks on price stability has resulted in greater resilience of Emerging Asia to external shocks. But other aspects of central bank policy have also played a role. In particular, capital account management policies and macroprudential policies have been used more actively since the AFC. Figure 2 provides illustrations. The left-hand panel shows that financial openness as measured by the Chinn-Ito index has declined both in the inflation-targeting economies mentioned above and in two economies which pursues the price stability objective less formally. The decline in openness has been particularly pronounced in Indonesia and Malaysia, the two economies that were most open prior to the AFC.

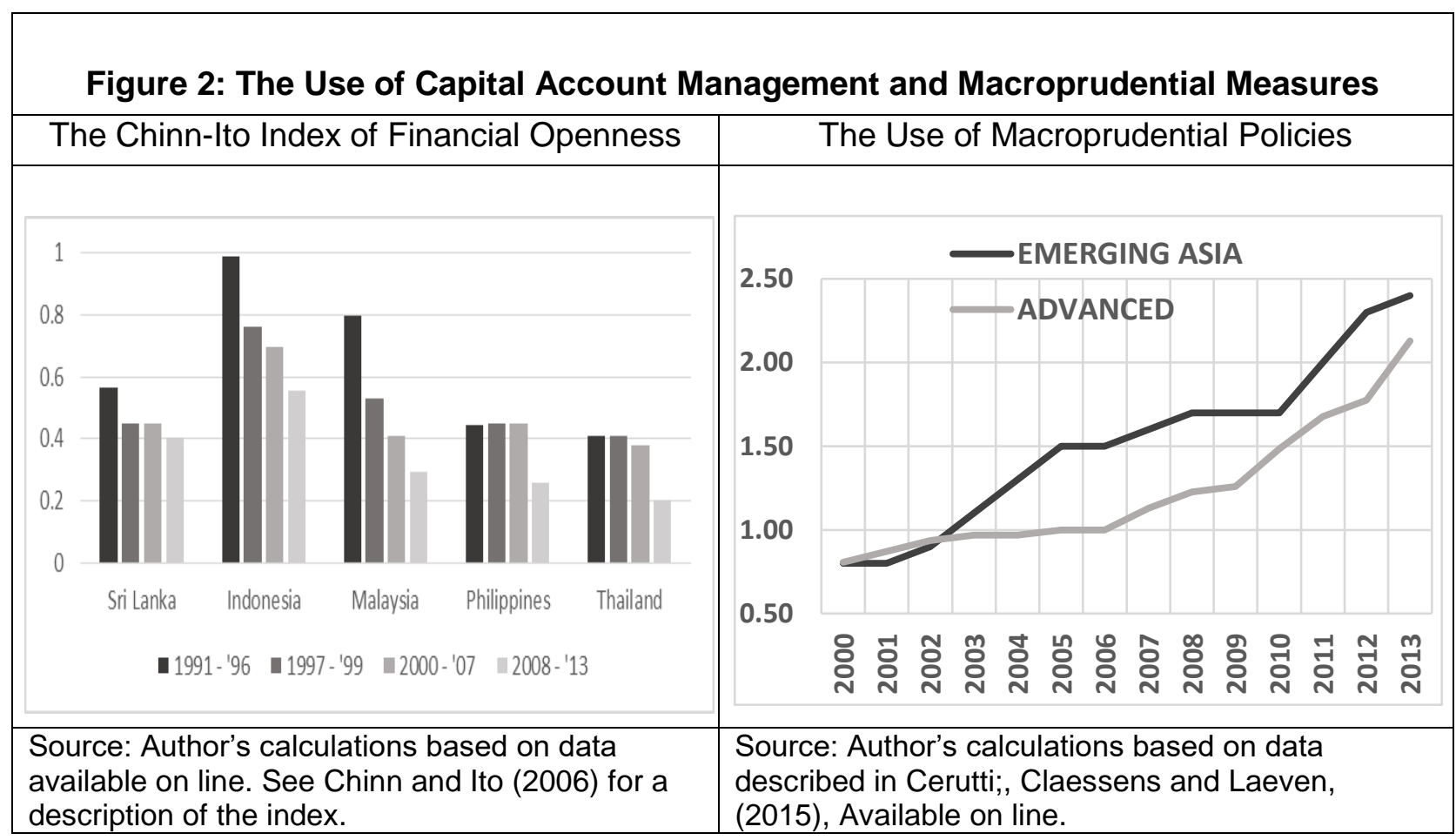

The right-hand panel in Figure 2 shows that the introduction of macroprudential policies in emerging Asia started shortly after the AFC, and is more widespread than in advanced economies. There is some evidence that these measures have had their intended effects. Data for Hong Kong indicate that restrictions on loan to value ratios for mortgage lending have reduced the size of mortgage loans and the frequency of non-performing loans on the balance sheets of 
regulated institutions. ${ }^{2}$ At the same time however, there are also indications that such restrictions placed on regulated banks has led property developers to propose mortgage financing thus shifting risks of mortgage default from banks to the developers.

In a study of four inflation-targeting Asian economies, Australia, Indonesia, Korea and Thailand, Kim and Mehrotra (2015) find that macroprudential policies have a significant impact on credit growth, a variable they use as a proxy for financial stability risks. Their results also imply that the same policies also affect macroeconomic stability in that they influence the evolution of inflation and output. The implication is that macroprudential policies and traditional interest rate policies need to be carefully coordinated if the objectives of financial and macroeconomic stability are both to be attained.

The fact that 'financial stability' is a concept that is difficult to measure implies that empirical evidence on the effectiveness of macroprudential policies will be based on indirect measures. There is thus a risk that the evidence captures the effects on symptoms of an underlying problem rather than the ultimate causes.

\section{Good Fortune}

While it is quite clear that policy frameworks and financial structures in Asia were considerably more resilient to external shocks before the GFC than they had been before the $\mathrm{AFC}$, it has also been suggested that two elements of good fortune may have played a role in shielding Asian finance from the most nefarious practices in some advanced economies. One of these elements would have been that there was less incentive to 'search for yield' by creating exotic financial products, since the return on conventional lending was considered adequate. $A$ related element was that the relatively less developed bank-dominated systems in Asia had not yet expanded into providing the kinds of 'sophisticated' products that became toxic in the United States and Europe.

\section{Potential Side Effects}

It has already been noted in the case of loan-to-value restrictions in Hong Kong that other lenders - in that case residential development entities - took over some of the business provided by regulated financial institutions. More generally since macroprudential policies are typically targeted at a particular type of institution, a particular financial activity, or the financial strength of investors it is an open question whether these policies are treating symptoms or underlying financial stability risks. Genberg and Zamorski (2015) argue that such targeted measures may

$2 \mathrm{He}(2014)$. 
well be successful in curbing the specific risks "... the more difficult question to answer is whether they succeed in significantly reducing overall financial risk in the economy, or whether the risk is transferred somewhere else in the financial system: from regulated banks to shadow banks or the capital market; from mortgage lending to credit-card lending; and from borrowing from commercial banks to borrowing from 'curb-market' money lenders. If so, the risk in the system may not decrease substantially but become more opaque. There is also a danger that the transfer of risk will beget additional macroprudential policies targeted at the new activities resulting in multiple layers of policies whose aggregate effects may be hard to assess." (Pages 18-19).

As macroprudential and capital account management policies become more comprehensive there is generally a need for increased coordination between multiple national policy authorities, not only between the central bank and a separate bank regulatory agency in jurisdictions where the two are separate, but also between the central bank and the fiscal authorities. The latter coordination is necessary when special legislation is needed to put measures into effect or when measures taken may have fiscal implications. Indeed, in several jurisdictions elaborate structures have been created to manage the coordination process. While coordination between the central bank and the fiscal authorities is certainly laudable in the area where there are policy overlaps, it begs the question whether it will affect central bank independence also in areas where it has been agreed that such independence is desirable to achieve macroeconomic stability.

\section{Concluding Remarks}

Asia's emerging market economies have evolved extensively since the Asian Financial Crisis, so much so that they have recovered much more fully from the GFC than advanced economies in Europe and the United States. Improved governance and policy frameworks have rendered the economies more resilient to external shocks. Central banks have embraced price stability as a vital objective, but they have also become less defensive about using policies that before the GFC were considered to be unorthodox by many observers in advanced economies, including institutions like the International Monetary Fund. These policies include interventions in the foreign exchange market, macroprudential policies, and capital flow management measures, and they are intended to complement traditional interest rate policies in pursuing financial stability as well as macroeconomic stability. 
But while the economies of emerging Asia are more resilient, they are still deeply exposed to shocks coming from developments in the global economy. These developments include persistently low interest rates in global financial markets that are transmitted to emerging markets, monetary policy divergences between the US Federal Reserve and the European Central Bank, and a potential toxic mix of expansionary fiscal policy and tight monetary policy in the United States. Central bankers and regulators in emerging markets thus need to be vigilant and be ready to respond to external developments by adapting and refining their policy frameworks. ${ }^{3}$

${ }^{3}$ See Genberg (2017), Filardo, Genberg, and Hofmann (2016), and Zamorski and Lee (2015). 


\section{References}

Cerutti, Eugenio; Stijn Claessens and Luc Laeven, (2015), "The Use and Effectiveness of Macroprudential Policies: New Evidence," IMF Working Paper, WP/15/61, Available from: http://www.imf.org/external/pubs/ft/wp/2015/wp1561.pdf

Chinn, Menzie D. and Hiro Ito, (2006), "What Matters for Financial Development? Capital Controls, Institutions, and Interactions," Journal of Development Economics, Volume 81, Issue 1, pp. 163-192, October.

Filardo, Andrew and Hans Genberg, (2010), "Targeting Inflation in Asia and the Pacific: Lessons from the Recent Past," in David Cobham; Oyvind Eitrheim; Stefan Gerlach and Jan F. Qvigstand, (Eds.), Inflation Targeting Twenty Years On: Past Lessons and Future Prospects, Cambridge: Cambridge University Press.

Filardo, Andrew; Hans Genberg and Boris Hofmann, (2016), "Monetary Analysis and the Global Financial Cycle: An Asian Central Bank Perspective," Journal of Asian Economics, 46, pp.1-16.

Genberg, Hans, (2017), "Global Shocks and Risks to Financial Stability in Asia," Mimeo, January.

Genberg, Hans and Michael Zamorski, (2015), "Implementing Macroprudential Policies: Challenges, Pitfalls, and Way Forward," SEACEN Financial Stability Journal, Vol. 4, May, pp. $9-26$.

He, Dong, (2014), "Macroprudential Policies: Implementation and Interactions," Financial Stability Review, No. 18, Banque de France, April.

Kim, Soyoung and Aaron Mehrotra, (2016), "Managing Price and Financial Stability Objectives What Can We Learn from the Asia-Pacific Region?" BIS Working Papers, No 533.

Zamorski, Michael and Minsoo Lee, (2015), "Banking Regulation in Asia," in Marcus Noland and Donghyun Park, (Eds.), From Stress to Growth: Strengthening Asia's Financial Systems in a Post-Crisis World, Peterson Institute for International Economics. 